\title{
Impact of Climate Variables on COVID-19 Pandemic in Asia: A Systematic Review
}

\author{
Yoerdy Agusmal Saputra ${ }^{1}$, Dewi Susanna ${ }^{2 *}$, Vernonia Yora Saki ${ }^{3}$
}

\author{
${ }^{1}$ Postgraduate Student, Faculty of Public Health, Universitas Indonesia, Depok, Indonesia \\ ${ }^{2}$ Department of Environmental Health, Faculty of Public Health, Universitas Indonesia, Indonesia \\ ${ }^{3}$ Department of Pharmacy, Faculty of Industrial Technology, Al-Kamal Institute of Science and Technology, Jakarta, Indonesia
}

\begin{abstract}
COVID-19 has become a global pandemic and threatens public health systems worldwide. Virus transmission can be influenced by several factors, one of which is climatic conditions. Temperature, humidity, precipitation, wind speed, and solar radiation play an important role in the transmission of infectious diseases and are variables that can determine the resistance of the SARS virus. This paper aimed to critically assess and provide evidence-based on the impact of climate variables on COVID-19 cases in Asia based on current knowledge to form the basis of guidelines for health care and prevention efforts. This systematic review used Preferred Reporting Items for Systematic Reviews and Meta-Analyses (PRISMA). The articles were searched from ProQuest, Scopus, PubMed, and Springerlink databases. The reviewers had screened 2.784 abstracts, 103 full-text publications, and ultimately included 11 systematic reviews. The review found a consistently positive relationship between climate variables and COVID-19. Average temperature, maximum temperature, minimum temperature, and humidity $(r=0.83,0.94,0.93,0.30)$ were significantly correlated with COVID-19 cases. Temperature, maximum humidity, and population density (adjusted R2 $=0.53, p<0.05$ ), can be used as references in planning interventions during potential future pandemics. Linear regression framework, high humidity, and high temperature $(p<0.05)$ significantly reduce the transmission of COVID-19. This systematic review shows that climate plays a role in the spread of the COVID-19 pandemic in Asia.
\end{abstract}

Keywords: climate change condition, COVID-19, humidity, precipitation, temperature

\section{Introduction}

Coronavirus Disease 2019 (COVID-19) has become a worldwide pandemic and threatens public health systems worldwide. There are many dynamics regarding the causative agent of COVID-19. Currently, SARS-CoV-2 (Severe Acute Respiratory Syndrome Coronavirus 2) was determined to be the cause. ${ }^{1}$ The COVID-19 is currently the third disease caused by the coronavirus transmitted from animals to humans. It was identified as a zoonotic coronavirus, similar to the SARS-CoV (Severe Acute Respiratory Syndrome Coronavirus) and MERS-CoV (the Middle East Respiratory Syndrome Coronavirus), which results in a severe respiratory syndrome after twenty years. ${ }^{2,3}$ As of August 31, 2020, a total of $24,854,140$ confirmed cases were reported worldwide, with 838,924 deaths (CFR 3.4\%) with cases reported in 216 countries/regions. ${ }^{4}$

Experts believe in the influence of seasons on viral epidemiology. Low temperature is the most optimal condition for viruses such as a respiratory syncytial virus

Correspondence*: Dewi Susanna, Department of Environmental Health, Faculty of Public Health, Universitas Indonesia, Building C 2nd Floor Kampus Baru Universitas Indonesia Depok 16424, Indonesia, E-mail: dsusanna@ui.ac.id;

dsusanna2@yahoo.com, Phone: +628121870252; Fax: +62217863469
(RSV), influenza virus, and human metapneumovirus (hMPV) to cause infection in humans. This season causes RSV and influenza cases to increase in winter, while hMPV cases occur most of the year and peak in winter and spring. ${ }^{5}$ The significant increase in the incidence of influenza at low temperatures and high humidity points to the potential impact of climatic conditions on the distribution and transmission of COVID-19, amid consideration of other non-climatic factors. ${ }^{6-9}$

Climatic conditions are the essential factors that affect COVID-19 because they can be a direct cause of biological interactions between agents and humans. Climatic elements such as temperature, humidity, rainfall, wind speed, and sunlight are significant factors in disease transmission and are parameters that can determine the survival of the SARS virus. ${ }^{10-12}$ Therefore, this systematic review aimed to critically assess and provide evidence-based on the impact of climate variables on COVID-19 cases in Asia based on current knowledge to form the basis of guidelines for health care and preven- 
tion efforts.

\section{Method}

\section{Search Strategy}

For this review, articles were sourced from four science databases; ProQuest, Scopus, Pubmed, and Springerlink. The systematic review was adjusted using the PRISMA guidelines. ${ }^{13}$ The searching process utilized two main keywords, which include climate and COVID-19. The population was people diagnosed with COVID-19. The comparison was countries, study characteristics, climate variables, the outcome was COVID-19, and the type of research using qualitative methods.

The search strategy in ProQuest: climate AND covid-19 as keywords. Full text, peer review, the source is an academic journal, date of publication last 12 months, English language are included in the filter. In Scopus: TITLE-ABS-KEY climate AND covid-19 AND (LIMIT-TO (ACCESSTYPE $(\mathrm{OA}))$ ) AND (LIMITTO(PUBYEAR,2020)) AND (LIMIT- TO(DOCTYPE, "ar")). In Pubmed: (("climate"[All Fields]) AND ("covid-19"[All Fields]). Full text, type of article is a journal article, date of publication last one year, English language are included in the filter. The search strategy in Springerlink: climate AND covid-19 as a keyword.

\section{Inclusion and Exclusion Criteria}

All original articles in English, academic or research articles, ecological and time-series research, and the articles looking at the correlation between climate (temperature, humidity, precipitation, wind speed, and sunlight) and COVID-19 cases were included. The study about the relationship between climate and COVID-19 recovery rates, COVID-19 reproduction rates, and variables related to COVID-19 in addition to the number of cases, review articles, case reports, outbreak reports, and qualitative method were excluded.

\section{Study Selection}

Three reviewers selected the research based on the eligibility of the articles to be reviewed from the title, abstract, and full text. Three reviewers were selecting the articles based on their area of expertise.

\section{Data Extraction}

Data taken based on the conditions met, among others, the author, the study period, the year of publication, the country carried out, the research design and research method, the research area, and the correlation between climate (temperature, humidity, precipitation, wind speed, and sunlight), and COVID-19 cases.

\section{Data Synthesis}

Data synthesis was carried out using narrative synthesis. The research area included countries in the Asian continent. The variables of climate reviewed were based on the local state meteorological and climatological agency. The number of COVID-19 cases was reviewed based on the diagnosis of COVID-19 cases recorded at the local state health department. To reduce the risk of bias, the three reviewers worked independently. It would be done through an online discussion process and reading all the selected articles if they have different opinions. The eligible articles were then analyzed qualitatively based on the five variables: temperature, humidity, precipitation, wind speed, and sunlight exposure. The review used a PRISMA guideline; a checklist has been carried out using the PRISMA Checklist 2020.

\section{Results}

The studies included in this review were 11 articles. From 11 studies, three studies were from India, two studies were from Turkey and Japan, and Bangladesh, Indonesia, Iran, China, and Gulf Countries each. The results were resumed in Table 1. Based on studies reviewed, temperature (average, minimum, maximum, ambient), humidity, wind speed, average precipitation, number of sunny days with COVID-19. The Average temperature was at $2 \mathrm{~m}(\mathrm{r}=0.83)$, maximum tempera-

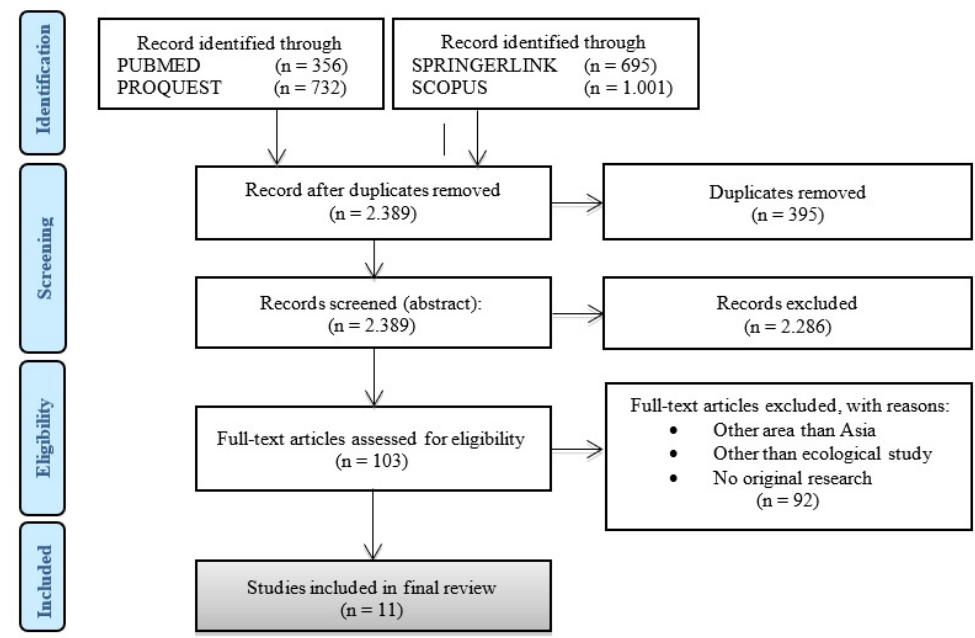

Figure 1. Systematic Review Flowchart 
Kesmas: Jurnal Kesehatan Masyarakat Nasional (National Public Health Journal). 2021; 16 (Special Issue 1): 82-89.

Table 1. Journals in Review ${ }^{14-24}$

\begin{tabular}{|c|c|c|c|c|c|c|}
\hline Title & Author & $\begin{array}{l}\text { Year } \\
\text { of Publish }\end{array}$ & Variable & Analysis & Result & Suggestion \\
\hline $\begin{array}{l}\text { Correlation between } \\
\text { weather and COVID- } 19 \\
\text { pandemic in India: } \\
\text { An empirical investigation }\end{array}$ & $\begin{array}{l}\text { Prayas Sharma, } \\
\text { Ashish Kumar } \\
\text { Singh, Bharti } \\
\text { Agrawal, Anukriti } \\
\text { Sharma }\end{array}$ & 2020 & $\begin{array}{l}\text { Temperature, } \\
\text { Humidity }\end{array}$ & $\begin{array}{l}\text { Pearson Product } \\
\text { Moment Correlation } \\
\text { Spearman's rank } \\
\text { correlation }\end{array}$ & $\begin{array}{l}\text { Minimum temperature }(\mathrm{r}=0.93) \text {, } \\
\text { maximum temperature }(\mathrm{r}=0.94) \text {, } \\
\text { average temperature }(\mathrm{r}=0.83) \text {, } \\
\text { and humidity }(\mathrm{r}=0.30) \text { were } \\
\text { significantly correlated with cases } \\
\text { of the COVID-19 pandemic with } \\
\text { two-tailed } 99 \% \text { significance level. }\end{array}$ & $\begin{array}{l}\text { The results of this } \\
\text { study might use for } \\
\text { further researchers in } \\
\text { this field and formulate } \\
\text { a policy in reducing the } \\
\text { spread of COVID-19 } \\
\text { in India. }\end{array}$ \\
\hline
\end{tabular}

Influence of Absolute

Humidity, Temperature and Population Density on COVID-19 Spread and Decay Duration: Multi-Prefecture Study in Japan

\section{Essam A. Rashed, 2020 Population} Sachiko Kodera, density, spread Jose Gomez-Tames, Akimas Hirata and decay duration,

Maximum temperature, Absolute humidity
Rank correlation, Population density with social

A correlation matrix distance is one of the main factors with partial correlation probabilities, Linear regression

influencing the distribution and damage pattern, with $\mathrm{R} 2=0.39$ $(\mathrm{p}<0.05)$ and $0.42(\mathrm{p}<0.05)$.
Maximum humidity affected decay duration, which was normalized by population density (R2 > 0.36, p < 0.05).

Based on multivariate analysis, it is known that the estimated duration of pandemic spread, maximum humidity, ambient temperature, and population density (adjusted R2 = 0.53 , p-value $<0.05$ ), is used to plan interventions during a potential future pandemic.
The spread of COVID-19 Hamit Coşkun, virus through population Nazmiye Yildırım, density and wind in Turkey cities Samettin Gündüz

\section{Temperature,} Humidity, Number of sunny days, Wind intensity
Regression analysis, Meditation analysis
Association between temperature, humidity, outbreaks in Bangladesh and COVID-19

$\begin{array}{llll}\text { Syed Emdadul } & 2020 & \text { Temperature } & \text { Linear regression } \\ \text { Haque, Mosiur } & & \text { average, } \\ \text { Rahman } & \text { Humidity, } & \\ & \begin{array}{l}\text { Summer and } \\ \text { rainy season }\end{array} & \end{array}$

Population density and wind are at risk of spreading the virus, with an estimated percentage of $94 \%$

Temperature, humidity, sun brightness, and air pollution did not affect the number of cases.

The number of COVID-19 cases is affected by the influental population density and wind speed.

The Sobel test showed a significant decrease (Sobel $\mathrm{z}=17.23, \mathrm{p}=0.0001$ ). There was a relationship between wind speed, density, and the case of COVID-19.

The peak spread of COVID- 19
occurred at an average temperature
of $26 \circ \mathrm{C}$.

A high temperature $(\mathrm{p}=0.038)$ and high humidity $(\mathrm{p}=0.005)$ significantly reduced COVID-19 transmission from the multiple linear mechanism. regression results. This climate factor indicates that the hot season and rainy season in Bangladesh can reduce COVID-19 cases.

\begin{tabular}{|c|c|c|c|c|c|c|}
\hline $\begin{array}{l}\text { Correlation between } \\
\text { weather and COVID-19 } \\
\text { pandemic in Jakarta, } \\
\text { Indonesia }\end{array}$ & $\begin{array}{l}\text { Ramadhan Tosepu, } \\
\text { Joko Gunawan, } \\
\text { Devi Savitry } \\
\text { Effendy, La Ode } \\
\text { Ali Imran Ahmad, } \\
\text { Hariati Lestari, } \\
\text { Hartati Bahar, } \\
\text { Pitrah Asfian }\end{array}$ & 2020 & $\begin{array}{l}\text { Minimum } \\
\text { temperature, } \\
\text { Maximum } \\
\text { temperature, } \\
\text { Temperature } \\
\text { average, Humidity, } \\
\text { Amount of rainfall }\end{array}$ & $\begin{array}{l}\text { Spearman-rank } \\
\text { correlation }\end{array}$ & $\begin{array}{l}\text { Based on the analysis results, a } \\
\text { significant relationship was found } \\
\text { between the average temperature } \\
\left({ }^{\circ} \mathrm{C}\right) \text { and COVID- } 19(\mathrm{r}=0.392 ; \\
\mathrm{p}=0.001) \text {. Other variables such as } \\
\text { minimum temperature, maximum } \\
\text { temperature, humidity, and rainfall } \\
\text { were not significantly correlated } \\
\text { with COVID- } 19 \text {. }\end{array}$ & $\begin{array}{l}\text { The findings can be } \\
\text { used as input for the } \\
\text { government to reduce } \\
\text { COVID-19 disease in } \\
\text { Indonesia. }\end{array}$ \\
\hline $\begin{array}{l}\text { Investigation of effective } \\
\text { effective climatology } \\
\text { parameters on COVID-19 } \\
\text { outbreak in Iran }\end{array}$ & $\begin{array}{l}\text { Mohsen Ahmadi, } \\
\text { Abbas Sharifi, } \\
\text { Shadi Dorosti, Saeid } \\
\text { Jafarzadeh Ghoushchi } \\
\text { Negar Ghanbari }\end{array}$ & 2020 & $\begin{array}{l}\text { Infected people with } \\
\text { COVID-19, density, } \\
\text { Intra-provincial } \\
\text { movement, Infection } \\
\text { days to end of the } \\
\text { study period, }\end{array}$ & $\begin{array}{l}\text { The Partial Corre- } \\
\text { lation Coefficient } \\
\text { (PCC), Sobol Jansen } \\
\text { methods, Analyzing } \\
\text { the effect and } \\
\text { correlation of }\end{array}$ & $\begin{array}{l}\text { The sensitivity analysis shows that } \\
\text { population density, intra-provincial } \\
\text { movement have a significant } \\
\text { correlation with COVID- } 19 \text {. } \\
\text { Areas with low humidity, wind }\end{array}$ & $\begin{array}{l}\text { Researchers should pay } \\
\text { attention to the } \\
\text { presence of this type of } \\
\text { virus every ten years by } \\
\text { providing results based } \\
\text { on previous experimen- }\end{array}$ \\
\hline
\end{tabular}

SARS-CoV-2, which is not visible in the air spreads faster in windy weather, indicating that SARS-CoV-2 in the air is one factor that threatens humans with wind speeds that increase air circulation.
Social distancing as a community intervention aims to prevent the spread of the virus is still important. Further laboratory studies are needed to determine the r
For similiar potential pandemics, especially a potential second wave COVID-19 pandemic, population density, spread and duration of decay, temperature, humidity should be considered, and multicity comparisons to develop different protection policies. 
Saputra et al., Impact of Climate Variables on COVID-19 Pandemic in Asia: A Systematic Review

Table 1. Journals in Review14-24

\begin{tabular}{|c|c|c|c|c|c|c|}
\hline Title & Author & $\begin{array}{l}\text { Year } \\
\text { of Publish }\end{array}$ & Variable & Analysis & Result & Suggestion \\
\hline & & & $\begin{array}{l}\text { temperature, } \\
\text { precipitation, } \\
\text { Humidity, Wind } \\
\text { speed, Average } \\
\text { solar radiation }\end{array}$ & $\begin{array}{l}\text { variables with the } \\
\text { COVID-19 } \\
\text { spreading rate }\end{array}$ & $\begin{array}{l}\text { speed, and solar radiation can } \\
\text { support the viability of the virus, } \\
\text { causing high infection rates. } \\
\text { Provinces with a high population } \\
\text { density, intra-provincial movement, } \\
\text { and high humidity levels in Tehran, } \\
\text { Mazandaran, Alborz, Gilan, and } \\
\text { Qom are more susceptible to } \\
\text { infection. }\end{array}$ & $\begin{array}{l}\text { tal and observational } \\
\text { studies and considering } \\
\text { how these factors may } \\
\text { affect the spread of } \\
\text { COVID-19. In addition, } \\
\text { a long-term study of the } \\
\text { world's climate can } \\
\text { anticipate the possibility } \\
\text { of a similar pandemic } \\
\text { occuring. }\end{array}$ \\
\hline $\begin{array}{l}\text { Impact of weather on } \\
\text { COVID-19 pandemic } \\
\text { in Turkey }\end{array}$ & Mehmet Şahin & 2020 & $\begin{array}{l}\text { Temperature, Dew } \\
\text { point, Humidity, } \\
\text { Wind speed, } \\
\text { Population }\end{array}$ & $\begin{array}{l}\text { Spearman's } \\
\text { correlation test }\end{array}$ & $\begin{array}{l}\text { Temperature associated with the } \\
\text { number of COVID- } 19 \text { cases. } \\
\text { The effect of humidity is the highest } \\
\text { on the day of the COVID-19 cases. } \\
\text { Wind speed correlates with } \\
\text { COVID-19 cases. } \\
\text { The population is a prominent } \\
\text { indicator of determining or estimating } \\
\text { COVID-19 cases. }\end{array}$ & $\begin{array}{l}\text { The results of this study } \\
\text { can be a guide for } \\
\text { authorities and decision- } \\
\text { makers in taking } \\
\text { specific steps for } \\
\text { pandemic control. }\end{array}$ \\
\hline
\end{tabular}

\begin{tabular}{|c|c|c|c|c|}
\hline $\begin{array}{l}\text { Effect of temperature } \\
\text { on the infectivity of } \\
\text { COVID-19 }\end{array}$ & $\begin{array}{l}\text { Mugen Ujiiea, } \\
\text { Shinya Tsuzukib, } \\
\text { Norio Ohmagari }\end{array}$ & 2020 & $\begin{array}{l}\text { Temperature, } \\
\text { Number of } \\
\text { COVID-19 cases }\end{array}$ & $\begin{array}{l}\text { Poison regression } \\
\text { analysis }\end{array}$ \\
\hline
\end{tabular}

COVID-19
Shinya Tsuzukib,
Norio Ohmagari

COVID-19 cases
The old-age dependency ratio, visitors arriving from China in January 2020, and the average temperature in February 2020 associated with the cumulative number of COVID- 19 cases as of March 16, 2020

Effect of temperature and S.A. Meo, A.A. humidity on the dynamics Abukhalaf, A.A. of daily new cases and Alomar, N.M. deaths due to COVID-19 Alsalame, T. Althe outbreak in Gulf khlaiwi, A.M. countries in Middle Usmani East Region
2020

The mean temperature and humidity were recorded from the appearance of the first case of COVID-19 in the region. The ratio by which quantity overcomes itself overtime; it is the same as the daily cases divided by the cases on the previous day
The data were recorded and analyzed; Mean and Standard Error of Mean (SEM) were calculated.

A correlation calculated between meteorological factors and daily new cases and deaths of COVID-19.

The growth factor, in which the quantity beats itself over time, The growth factor result for daily was calculated.
The daily basis mean temperature was $29.20 \pm 0.30^{\circ} \mathrm{C}$, and humidity was $37.95 \pm 4.40 \%$.

There was a negative correlation in the number of daily cases and deaths with the increase of the humidity in Oman, Kuwait, Qatar, Bahrain, United Arab Emirates, and Saudi Arabia.

There was a correlation between increasing the temperature and the increase in daily cases and deaths due to COVID-19.

The growth factor result for daily
cases were $1.09 \pm 0.00$, and daily deaths were $1.07 \pm 0.03$ for COVID-19. This result showed the declining trends in the GCC region.
There may be a link between low temperatures and an increased risk of COVID-19 infection. Further evaluations will be carried out at the global level.

These findings can be used to reference policy makers and health officials based on the epidemiological trends of the impact of temperature and humidity of daily new cases and deaths from COVID-19.

This model was significantly able to This research indicates predict the number of COVID-19 that the COVID-19 cases, $\mathrm{F}(4.56)=1213.61, \mathrm{p}=0.001$, pandemic may not be with a value of $99.4 \%$ of the suppressed by increasing variation of COVID-19 cases with temperatures and adjusted R2 $=98.8 \%$. Maximum humidity. However, it is temperature, temperature, and average relative humidity did not show statistically significance. critical to increase testing capacity to achieve epidemiological understanding and guide policy determination for COVID-19. 
Kesmas: Jurnal Kesehatan Masyarakat Nasional (National Public Health Journal). 2021; 16 (Special Issue 1): 82-89.

Table 1. Journals in Review ${ }^{14-24}$

\begin{tabular}{|c|c|c|c|c|c|c|}
\hline Title & Author & $\begin{array}{c}\text { Year } \\
\text { of Publish }\end{array}$ & Variable & Analysis & Result & Suggestion \\
\hline $\begin{array}{l}\text { Significance of } \\
\text { geographical factors } \\
\text { to the COVID-19 } \\
\text { outbreak in India }\end{array}$ & $\begin{array}{l}\text { Amitesh Gup, } \\
\text { Sreejita Banerjee, } \\
\text { Sumit Das }\end{array}$ & 2020 & $\begin{array}{l}\text { Air temperature, } \\
\text { Rainfall, Actual } \\
\text { evapotranspirator } \\
\text { ion, Solar radiation } \\
\text { Specific humidity, } \\
\text { Wind speed with } \\
\text { topographic altitude, } \\
\text { The population } \\
\text { density at the local } \\
\text { level to investigate } \\
\text { the spatial } \\
\text { relationship with } \\
\text { the number of } \\
\text { COVID-19 } \\
\text { infections }\end{array}$ & $\begin{array}{l}\text { Pearson product- } \\
\text { moment correlation } \\
\text { Partial least } \\
\text { square regression } \\
\text { Generalized } \\
\text { additive model }\end{array}$ & $\begin{array}{l}\text { The spatial distribution of COVID-19 } \\
\text { cases in India shows that maximum } \\
\text { transmission occurs in countries } \\
\text { with fewer wet conditions. However, } \\
\text { provinces with the wet and very } \\
\text { wet categories were less likely to } \\
\text { be infected by the transmission. } \\
\text { The bivariate analysis found no } \\
\text { significant relationship with the } \\
\text { number of infected cases in } 36 \\
\text { provinces in India. The Variable } \\
\text { Importance Projection (VIP) } \\
\text { through the Partial Least Square } \\
\text { (PLS) technique signifies the } \\
\text { higher importance of SR, T, R, } \\
\text { and AET. However, a general } \\
\text { additive model that is equipped } \\
\text { with the log transformation values } \\
\text { input variables and applying } \\
\text { spline fix to PD and E, there is a } \\
\text { very high prediction accuracy } \\
\text { (R2 = 0.89); therefore, there is a } \\
\text { well-explained complex heterogeneity } \\
\text { among parameter associations in the } \\
\text { region with COVID-19 cases in India. }\end{array}$ & $\begin{array}{l}\text { The positive relationship } \\
\text { with SR and temperature } \\
\text { and the negative } \\
\text { relationship with humidity } \\
\text { and rainfall indicate that } \\
\text { areas with high temperatu- } \\
\text { re and arid in lowland } \\
\text { areas are advised to be } \\
\text { more stringent in } \\
\text { following up on emergency } \\
\text { precautions. }\end{array}$ \\
\hline
\end{tabular}

ture at $2 \mathrm{~m}(\mathrm{r}=0.94)$, minimum temperature at $2 \mathrm{~m}(\mathrm{r}=$ 0.93), and humidity at $2 \mathrm{~m}(\mathrm{r}=0.30)$ were significantly correlated with cases of the COVID-19 pandemic with two-tailed 99\% significance level. Ambient temperature, maximum absolute humidity, and population density (adjusted R2 $=0.53$, p-value $<0.05$ ), proved useful for planning interventions during potential future pandemics, including the second COVID-19 outbreak. Average temperature $\left({ }^{\circ} \mathrm{C}\right)$ correlated significantly with the COVID-19 pandemic $(r=0.392 ; p<0.01)$. Linear regression framework, high humidity $(p=0,005)$ and high temperature $(p=0,038)$ significantly reduce the transmission of COVID-19. These results show that the arrival of the hot summer and rainy season in Bangladesh can effectively reduce the transmission of COVID-19. In Iran, regions with low wind speed values, average precipitation, humidity, and solar radiation exposure to a high infection rate support the virus's survival.

\section{Discussion \\ Temperature}

In the studies reviewed, the temperature was significantly associated with the incidence of daily COVID-19 with and without time lag. Therefore, it was concluded that temperature drives the spatial and temporal correlation of the COVID-19 outbreak in China. It should be considered the optimal climate predictor for the incidence of COVID-19.25 Several flu viruses that occur in northern states are caused by flu viruses of the same family type. This flu has a cyclic pattern of events known as "flu season." The flu virus was widespread during fall and winter and reached its peak between December and May. ${ }^{26}$ Worldwide, cases of human morbidity and mortality from COVID-19 continue to increase in the "flu season," but COVID-19 was not the flu. Data obtained from the China National Meteorological Center and the Hong Kong Observatory, China, shows that the COVID-19 outbreak occurred during winter, similar to the previous SARS epidemic outbreak. ${ }^{9}$

Research conducted in 122 cities in China found a significant relationship between average temperature and the number of positive cases of COVID-19. ${ }^{27}$ Also, the relationship between temperature and COVID-19 covering all countries affected by COVID-19, showed the result of an increase in daily temperature by an average of one degree Fahrenheit reduced the number of cases by about 6.4 cases/day. There is a negative correlation between the average temperature per country and the number of SARS-CoV-2 infection cases. This association remains strong even incorporating additional variables and controls (maximum temperature, average temperature, minimum temperature, and precipitation) and fixed state effects. ${ }^{10}$

The study explained that temperature was significantly associated with daily COVID-19 incidence with and without lag time. In addition, the researchers also found that the rate of transmission decreased as the temperature increased and that the increase in temperature contributed to a further decrease in infection rates and outbreak size. Therefore, it is concluded that temperature 
drives the spatial and temporal correlation of the COVID-19 outbreak in China and should be considered as the optimal climate predictor for the incidence of COVID-19.25 A research conducted by Bashir et al. (2020) in New York, USA, confirms that there are significant results between the mean temperature and the total cases and deaths from COVID-19.28

\section{Humidity}

High humidity, associated with low temperature, is an essential factor in influenza virus transmission, either by maintaining virulence or weakening the host by cooling the body or drying out the respiratory tract. ${ }^{29}$ The literature shows that SARS-CoV transmission is similar to the influenza virus in terms of climate fluctuations. ${ }^{30}$ The relationship between humidity and COVID-19 cases can be proven by the research conducted by Liu et al. (2020) in 30 provincial capitals in China that show a statistically significant relationship between absolute humidity and the number of COVID-19 cases. In addition, the association increased with the accumulated time duration up to 14 days. The study concluded that meteorological factors, particularly absolute humidity, played an independent role in the transmission of COVID-19 after controlling for population migration. Local weather conditions with low temperatures, mild diurnal temperature ranges, and low humidity tend to favor transmission. ${ }^{31}$

A similar study was conducted by Oliveiroset al. (2020) in 31 provinces in Mainland China, whose results show that humidity has a negative correlation with the doubling time of COVID-19 cases. This result means that, when humidity is low, the doubling time of COVID-19 cases will be longer, so the rate of progression of COVID-19 is expected to be slower. However, humidity and temperature variables only contributed up to a maximum of $18 \%$ of the variation. In comparison, the remaining $82 \%$ was related to other factors such as controlling population mobilization, public health policies, population density, transportation, and cultural aspects. ${ }^{8}$

\section{Precipitation}

Precipitation was one of the climatic factors which seem to be an essential factor to consider. Based on research conducted by Sobralet al. (2020), covering all countries affected by COVID-19 showed a positive correlation between precipitation and transmission of SARS-CoV-2. Countries with higher rainfall measurements show an increase in disease transmission. For every inch of increase in mean/day rainfall, there was an increase of 56.01 cases/day. ${ }^{10}$

In contrast to research conducted by Menebo (2020) which examined the relationship between temperature and precipitation with daily new cases of COVID-19 in Norway, it was shown that among the seven weather variables studied, maximum temperature and the normal temperature had a positive and significant correlation with COVID-19. On the other hand, the rainfall measured at 7.00 a.m. has a negative and significant correlation with COVID-19, which means that the higher the rainfall, the lower the cases of COVID-19. Various arguments can be given for the negative relationship between rainfall and new cases. One of them was the hypothesis that people will avoid going out if it rains. On the other hand, people are more prone to breaking the 'stay at home' rule when the sun is shining outside, thus becoming exposed to the virus. ${ }^{32}$

\section{Wind Speed}

The wind was implied as a critical climatic factor for the transmission of COVID-19. However, studies on this factor were still minimal. ${ }^{33}$ Based on research conducted by Rosario et al. (2020), who conducted a study on the relationship between weather and COVID-19 cases in tropical countries showed that wind speed had a negative correlation $(\mathrm{p}<0.01)$. Therefore, high temperatures and wind speed were potential factors to reduce the spread of COVID-19.34

Research conducted by Coşkun et al. (2020) has had a different result. Research conducted by collecting climate values (temperature, humidity, number of sunny days, wind intensity) from 81 provinces in Turkey in March 2020 shows that population density and wind effectively spread the virus. These two factors explain $94 \%$ of the variance in the spreading virus. In addition, population density mediates the effect of wind speed (9\%) on the number of COVID-19 cases. The finding that the invisible COVID-19 virus in the air spreads more in windy weather suggests that airborne viruses threaten humans with wind speeds that increase air circulation. ${ }^{16}$

\section{Sunlight Exposure}

The results of research conducted by Rosario et al. (2020) in Rio de Janeiro, Brazil, showed a strong negative correlation between solar radiation and the incidence of COVID-19 ( $r=0.609, p<0.01)$. This result means that high solar radiation can reduce the incidence of COVID-19. ${ }^{34}$ This research is in line with the study conducted by Ratnesar-Sumate et al. (2020), who proved that sunlight could kill SARS-CoV-2 on the surface. This study also demonstrated the effectiveness of natural sunlight as a disinfectant for contaminated non-permeable surfaces. ${ }^{11}$

Based on research conducted by Asyary and Veruswati (2020), it was found that a higher duration of sunlight exposure was also associated with more case recovery from COVID-19 in patients. Sunlight can maintain the health condition of COVID-19 patients so that they have a chance to recover. Sunlight boosted the immune system, which slows down the development of influenza and SARS agents in the human body. ${ }^{35,36}$ 
Kesmas: Jurnal Kesehatan Masyarakat Nasional (National Public Health Journal). 2021; 16 (Special Issue 1): 82-89.

\section{Limitations}

This systematic review had some limitations. There were only 11 articles that met the inclusion criteria, and most of the articles did not examine the climate element thoroughly, thus affecting the results of the analysis. Due to the lack of controlled studies, a meta-analysis was not performed. This study could only see the relationship/ correlation and did not analyze the causal relationship. In addition, this study used secondary data so that the level of bias is less controllable.

\section{Conclusion}

This systematic review found a positive association between temperature (average, minimum, maximum, ambient), humidity, wind speed, average precipitation, number of sunny days with COVID-19. This systematic review shows that climate plays a role in the spread of the COVID-19 pandemic in Asia. The results of this review might be used as a reference for researchers to conduct further research. In addition, it can also be used as input for policymakers as a reference for the preparation of the COVID-19 pandemic prevention program.

\begin{abstract}
Abbreviations
AET: Actual Evapotranspiration; T: Temperature; COVID-19: coronavirus disease 2019; hMPV: Human Metapneumovirus; MERS-CoV: Middle East Respiratory Syndrome Coronavirus; PRISMA: Preferred Reporting Items for Systematic Review and Meta-Analyses; PCC: Partial Correlation Coefficient; PLS: Partial Least Square; PD: Population Density; R: Rainfall; RSV: Respiratory Syncytial Virus; SARS-CoV: Severe Acute Respiratory Syndrome Coronavirus; SARSCoV-2: Severe Acute Respiratory Syndrome Coronavirus 2; SR: Solar Radiation; SH: Specific Humidity; SEM: Standard Error of Mean; VIP: Variable Importance Projection; WS: Wind Speed.
\end{abstract}

\section{Ethics Approval and Consent to Participate}

This study was approved by the Research and Community Engagement Ethical Committee, Faculty of Public Health, Universitas Indonesia, No. 210/UN2.F10.D11/PPM.00.02/2021.

\section{Competing Interest}

The authors declare that there is no competing interest.

\section{Availability of Data and Materials}

For this review, articles were sourced from four science databases: ProQuest, Scopus, Pubmed, and Springerlink.

\section{Reporting Guidelines}

The PRISMA Flowchart has a temporary link

https://doi.org/10.6084/m9.figshare.14977866.v1 $1^{37}$

and the PRISMA Checklist in the link

https://doi.otg/10.6084/m9.figshare.14977926. ${ }^{38}$

\section{Authors' Contribution}

DS contributed substantially to the concept, work design, acquisition of the funding, and submitting the reporting guidelines to Figshare.com. YAS conducted data analysis, data interpretation, and drafting of the manuscript. VYS revised it critically for the important intellectual content of YAS, DS, and final approval of the version to be published.

\section{Acknowledgment}

The authors would like to thank the Ministry of Research and Technology of the Republic of Indonesia grant for financial support in contract No. NKB-474/UN2.RST/HKP.05.00/2020.

\section{References}

1. Kementerian Kesehatan Republik Indonesia. Pedoman pencegahan dan pengendalian coronavirus disease (COVID-19). 5th ed. Aziza L, Aqmarina A, Ihsan M, editors. Kementerian Kesehatan RI. Jakarta: Kementerian Kesehatan RI. 2020 p. 1-214.

2. Briz-Redón Á, Serrano-Aroca Á. A spatio-temporal analysis for exploring the effect of temperature on COVID-19 early evolution in Spain. Sci Total Environ. 2020 [cited 2020 July 21];728.

3. Lai CC, Shih TP, Ko WC, Tang HJ, Hsueh PR. Severe acute respiratory syndrome coronavirus 2 (SARS-CoV-2) and coronavirus disease2019 (COVID-19): the epidemic and the challenges. Int J Antimicrob Agents. 2020 [cited 2020 July 21];55(3).

4. World Health Organization. Coronavirus disease 2019 (COVID-19): situation report; 2020.

5. World Health Organization. Report of the WHO-China joint mission on coronavirus disease 2019 (COVID-19). Geneva; 2020 [cited 2020 Aug 1].

6. Park J, Son W, Ryu Y, Choi SB, Kwon O, Ahn I. Effects of temperature, humidity, and diurnal temperature range on influenza incidence in a temperate region. Influenza Other Respi Viruses. 2020 [cited 2020 Jul 21];14(1):11-8.

7. Bao J, Wang Z, Yu C, Li X. The influence of temperature on mortality and its lag effect: a study in four Chinese cities with different latitudes. BioMed Cent Public Heal. 2016 [cited 2020 Jul 21];16(1):1-8.

8. Oliveiros B, Caramelo L, Ferreira NC, Caramelo F. Role of temperature and humidity in the modulation of the doubling time of COVID19 cases. medRxiv; 2020 [cited 2020 Jul 21].

9. Adedokun KA, Olarinmoye AO, Mustapha JO, Kamorudeen RT. A close look at the biology of SARS-CoV-2, and the potential influence of weather conditions and seasons on COVID-19 case spread. Infect Dis Poverty. 2020 [cited 2020 Aug 1];9(1).

10. Sobral MFF, Duarte GB, da Penha Sobral AIG, Marinho MLM, de Souza Melo A. Association between climate variables and global transmission of SARS-CoV-2. Sci Total Environ. 2020;729:138997.

11. Ratnesar-Shumate S, Williams G, Green B, Krause M, Holland B, Wood S, et al. Simulated sunlight rapidly inactivates SARS-CoV-2 on surfaces. J Infect Dis. 2020;222(2):214-22.

12. Dalziel BD, Kissler S, Gog JR, Viboud C, Bjørnstad ON, Metcalf CJE. Urbanization and humidity shape the intensity of influenza epidemics in U.S. Cities. Science. 2018;362(6410):75-79.

13. Page MJ, McKenzie JE, Bossuyt PM, Boutron I, Hoffmann TC, Mulrow CD, et al. The PRISMA 2020 statement: an updated guideline for reporting systematic reviews. BMJ. 2021 [cited 2021 July 11];372.

14. Sharma P, Singh AK, Agrawal B, Sharma A. Correlation between weather and COVID-19 pandemic in India: an empirical investigation. J Public Aff; 2020.

15. Rashed EA, Kodera S, Gomez-Tames J, Hirata A. Influence of absolute humidity, temperature and population density on COVID-19 spread and decay durations: multi- prefecture study in Japan. Int J 
Environ Res Public Health. 2020;17(15):5354.

16. Coşkun H, Yıldırım N, Gündüz S. The spread of COVID-19 virus through population density and wind in Turkey cities. Sci Total Environ. 2020;751:141663.

17. Haque SE, Rahman M. Association between temperature, humidity, and COVID-19 outbreaks in Bangladesh. Environ Sci Policy. 2020 [cited 2021 Feb 9];114:253-5.

18. Tosepu R, Gunawan J, Effendy DS, Ahmad LOAI, Lestari H, Bahar H, et al. Correlation between weather and COVID-19 pandemic in Jakarta, Indonesia. Sci Total Environ. 2020;725.

19. Ahmadi M, Sharifi A, Dorosti S, Jafarzadeh Ghoushchi S, Ghanbari N. Investigation of effective climatology parameters on COVID-19 outbreak in Iran. Sci Total Enviro. 2020;729:138705.

20. Şahin M. Impact of weather on COVID-19 pandemic in Turkey. Sci Total Environ. 2020 [cited 2020 Jul 29];728:138810.

21. Ujiie M, Tsuzuki S, Ohmagari N. Effect of temperature on the infectivity of COVID-19. Int J Infect Dis. 2020;95:301-3.

22. Meo SA, Abukhalaf AA, Alomar AA, Alsalame NM, Al-Khlaiwi T, Usmani AM. Effect of temperature and humidity on the dynamics of daily new cases and deaths due to COVID-19 outbreak in Gulf countries in Middle East Region. Eur Rev Med Pharmacol Sci. 2020;24(13):7524-33.

23. Ladha N, Bhardwaj P, Charan J, Mitra P, Goyal JP, Sharma P, et al. Association of environmental parameters with COVID-19 in Delhi, India. Indian J Clin Bioche. 2020;35(4):497-501.

24. Gupta A, Banerjee S, Das S. Significance of geographical factors to the COVID-19 outbreak in India. Model Earth Syst Environ. 2020 p. 1-9.

25. Shi P, Dong Y, Yan H, Zhao C, Li X, Liu W, et al. Impact of temperature on the dynamics of the COVID-19 outbreak in China. Sci Total Environ. 2020;728(77):138890.

26. Centers for Disease Control and Prevention. The flu season. National Center for Immunization and Respiratory Diseases (NCIRD); 2018 [cited 2020 August 1].

27. Xie J, Zhu Y. Association between ambient temperature and COVID19 infection in 122 cities from China. Sci Total Environ. 2020;724:138201.

28. Bashir MF, Ma B, Bilal, Komal B, Bashir MA, Tan D, et al. Correlation between climate indicators and COVID-19 pandemic in New York, USA. Sci Total Environ. 2020;728:138835.
29. Jaakkola K, Saukkoriipi A, Jokelainen J, Juvonen R, Kauppila J, Vainio $\mathrm{O}$, et al. Decline in temperature and humidity increases the occurrence of influenza in cold climate. Environ Heal. 2014 [cited 2020 August 5];13(22):1-9

30. Lin K, Fong DY-T, Zhu B, Karlberg J. Environmental factors on the SARS epidemic: air temperature, passage of time and multiplicative effect of hospital infection. Epidemiol Infect. 2005 [cited 2020 Jul 21];134(2):223-30.

31. Liu J, Zhou J, Yao J, Zhang X, Li L, Xu X, et al. Impact of meteorological factors on the COVID-19 transmission: a multi-city study in China. Sci Total Environ. 2020;726:138513.

32. Menebo MM. Temperature and precipitation associate with COVID-19 new daily cases: a correlation study between weather and COVID-19 pandemic in Oslo, Norway. Sci Total Environ. 2020 [cited 2020 July 29];1-5.

33. She J, Jiang J, Ye L, Hu L, Bai C, Song Y. 2019 Novel coronavirus of pneumonia in Wuhan, China: emerging attack and management strategies. Clin Transl Med. 2020 [cited 2020 August 5];9(1).

34. Rosario DKA, Mutz YS, Bernardes PC, Conte-Junior CA. Relationship between COVID-19 and weather: case study in a tropical country. Int J Hyg Environ Health; 2020.

35. Asyary A, Veruswati M. Sunlight exposure increased COVID-19 recovery rates: a study in the central pandemic area of Indonesia. Sci Total Environ. 2020 [cited 2020 Jul 27];729:1-4.

36. Miller B. Immune system: your best defense against viruses and bacteria from the common cold to the SARS virus. Selangor Darul Ehsan: Oak Publication Sdn Bhd. 2018 p. 1-34.

37. Susanna D, Saputra YA, Saki VY. PRISMA Flowchart for Impact of Climate Variables on COVID-19 Pandemic in Asia: A Systematic Review. 2021 [cited 2021 Jul 28]. p. 1.

38. Susanna D, Saputra YA, Saki VY. PRISMA check-list for Impact of Climate Variables on COVID-19 Pandemic in Asia: A Systematic Review. 2021 [cited 2021 Jul 28]. p. 1. 